\title{
STUdy ON POWder MiXed Elecrtical Discharge Machining Process: A Review
}

\author{
ROUNIYAR, A. K. \& SHANDILYA, P.
}

Abstract: Powder mixed electric discharge machining (PM-EDM) process is a hybrid machining process by which the required profile is attained using thermal energy of sparks between tool and workpiece with addition of powder in dielectric fluid at low pulse energy. PM-EDM process enhances the capabilities of EDM process on machining of difficult to cut materials. This chapter explores the findings of research work carried out so far in the domain of PM-EDM of different hard and conductive materials. The effect of aided conductive powder into the dielectric fluid, electrical and non-electrical EDM process parameters on performance characteristics for machining various advanced materials has been studied under this chapter. This chapter also reviewed the industrial and academic work performed by various researchers from the origin to development of PM-EDM over the past decades. The research findings with major challenges along with the future scope have also been paved out.

Key words: PM-EDM, process parameters, performance parameters, powder
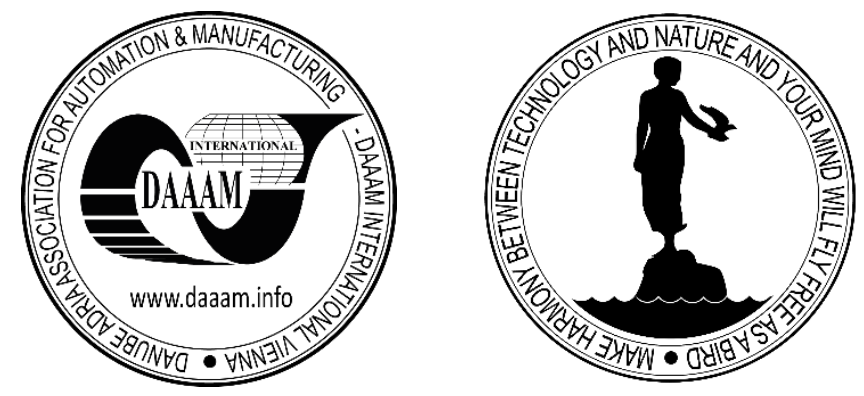

Authors' data: Rouniyar, A[run] K[umar]; Shandilya, P[ragya], Department of Mechanical Engineering, Motilal Nehru National Institute of Technology Allahabad, Prayagraj, India, pragya20@mnnit.ac.in

This Publication has to be referred as: Rouniyar, A[run] K[umar] \& Shandilya, P[ragya] (2019). Study on Powder Mixed Elecrtical Discharge Machining Process: A Review, Chapter 10 in DAAAM International Scientific Book 2019, pp.123-142, B. Katalinic (Ed.), Published by DAAAM International, ISBN 978-3-902734-24-2, ISSN 1726-9687, Vienna, Austria

DOI: $10.2507 /$ daaam.scibook.2019.10 


\section{Introduction}

At present era, applications of advanced materials such as ceramics, hardened steels, composites, and super alloys are in various fields namely in automobile, aerospace, missiles, nuclear reactors and marine industries. The applications are owing to its remarkable properties viz. high thermal conductivity, hardness, strength and better corrosion resistance (Singh and Yeh, 2012; Singh et al., 2010; Rouniyar and Shandilya, 2019b). Thus, for machining of the advanced materials, today's machining industries are facing challenges for achieving the higher machining rate, better surface morphology and an accuracy of machined components with the traditional machining as well as non-traditional machining process (Vishwakarma et al., 2012; Rouniyar and Shandilya, 2019c). Non-traditional machining process such as abrasive water jet machining, laser machining, electrical discharge machining (EDM), plasma machining were used for machining of advanced materials. However, EDM was found most suitable for machining of advanced conductive materials irrespective of material hardness. In this process, removal of materials occurs due to spark energy that melts and evaporates the material from the surface of electrodes when both electrodes immersed in dielectric. Lower machining rate, higher surface roughness, presence of residual stress and higher crack limits the use of EDM process at higher production scale. Hence, it is essential to improve and develop the new machining technology, which can machine the advanced materials with required features and eliminate the drawbacks of EDM process. Therefore, the researchers have developed hybrid-machining technology with the aid of powder particles mixed in dielectric fluid in EDM known as powder mixed EDM. The advantages of machining the advance materials with PM-EDM process include increment in MRR, lesser surface cracks, lower surface roughness and increase in corrosion resistance (Choudhary and Jadoun, 2014; Cogun et al., 2006). Applications of PM-EDM process are in the areas of automotive, military, surgical, defence and aviation industries for machining of parts and accessories (Talla et al. 2015; Rouniyar and Shandilya, 2019d).

In this paper, critical review of research on machining of difficult to cut conductive materials using PM-EDM process has been focussed. The author has explored the PM-EDM material removal mechanism, effect of different powders impregnated in dielectric and process parameters on various performance characteristics. The current scenarios on PM-EDM of diffucilt to cut materials such as metal matrix composites, titanium alloys, different grades of steels, and nickel based super alloys have been discussed in depth. The future scope of research work is also highlighted towards the last section of this chapter.

\subsection{Principle of powder mixed electrical discharge machining}

The mechanism of material removal in PM-EDM is different from the machining mechanism of traditional EDM. Figure 1(a) shows the principle of the PM-EDM mechanism (Kansal et al., 2005). 
The mechanism of material removal in PM-EDM is divided into four parts i.e. bridge formation of powder particles mixed in dielectric fluid, spark commencement due to breakage of a chain of powder, a zigzag motion of the particle due to explosion and re-bridging of powder particles as shown in Fig. 1(b) (Vhatkar and Jadhav, 2013). On application of 70-315 V voltage across the electrodes, electrical field intensity in the range of $10^{5}$ to $10^{7} \mathrm{~V} / \mathrm{m}$ has been produced. Under the influence of the electric field, the conductive powder particles present in the sparking area has energized. These conductive powders form the chains like structure by bridging the spark gap between the workpiece and the tool causing an early explosion. Thus the reduction of dielectric strength and gap voltage occurs, which increases the frequency of discharging causing faster erosion from the surface of the workpiece. The discharge particles behave in a zigzag motion and spread uniformly in all directions causing enlargement and widening of discharge passage resulting in a reduction of discharge density and enhancement of discharge heat area. Thus due to the reduction in the discharge density uniformly distributed shallow crater is formed improving the surface finish (Tripathy and Tripathy, 2016; Singh et al., 2010; Roy et al., 2016).

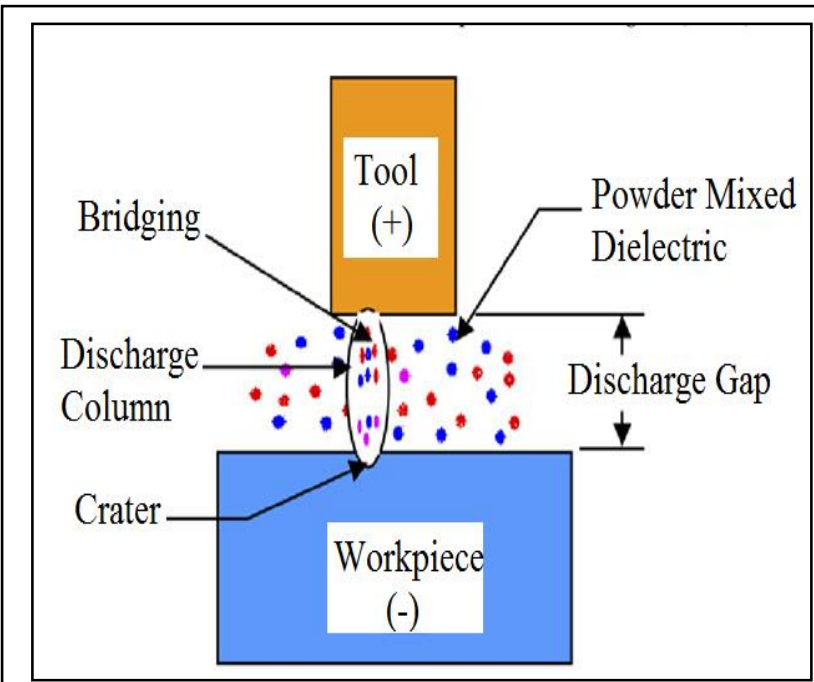

(a)

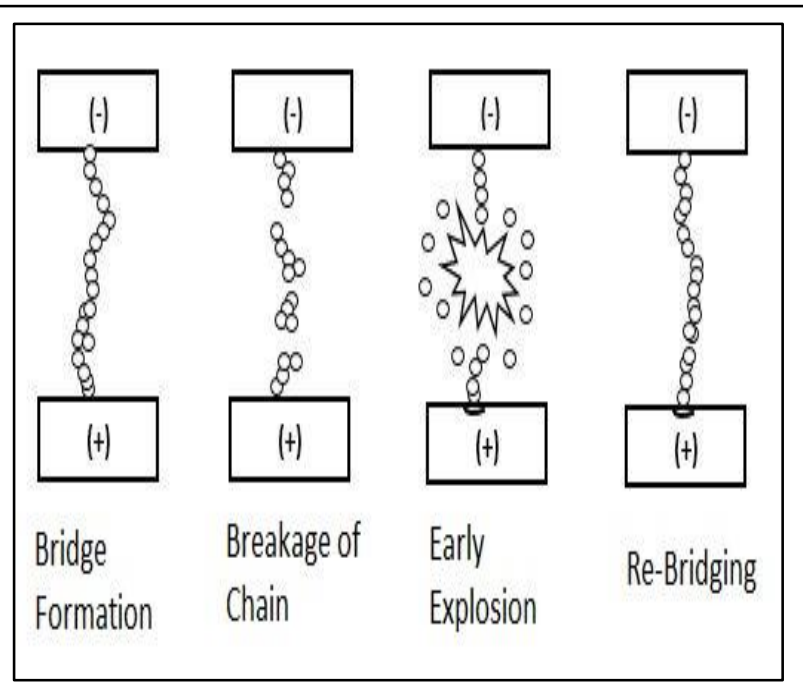

(b)

Fig. 1. (a) Principle of PM-EDM (Kansal et al., 2005), (b) Particles arrangement (Vhatkar and Jadhav, 2013)

\section{Experimental Setup}

The experimental machining setup for PM-EDM comprises of five elements as shown in Fig. 2 (Gugulothu et al., 2015; Marashi et al., 2015). Dielectric Circulation system an integral element of PM-EDM setup contains the circulating pump and dielectric fluid that clears debris under the inter-electrode gap by flushing. It also helps in maintaining the temperature of dielectric below its flash point, reusing of powder, cooling of tool and workpiece (Kumar et al., 2011). Power supply system called as mother of system controls the current, polarity, voltage, pulse duration and spark frequency to produce effective spark for removal of materials. 
Rouniyar, A. K. \& Shandilya, P.: Study on Powder Mixed Elecrtical Discharge Ma...

The servo-controlled feed system helps in adjustment of spark gap between the tool and workpiece resulting in proper sparking so that stable and efficient machining occurs. Stirring system comprises of pulley, belt, stirrer, and DC motor.

The stirring system ensures the proper mixing of powder particles in dielectric and avoids settlement of powder at bottom of tank (Ekmekci et al., 2016; Rajendra and Rao, 2014; Rouniyar and Shandilya, 2019a). Figure 3 illustrates the schematic diagram of the PM-EDM setup.

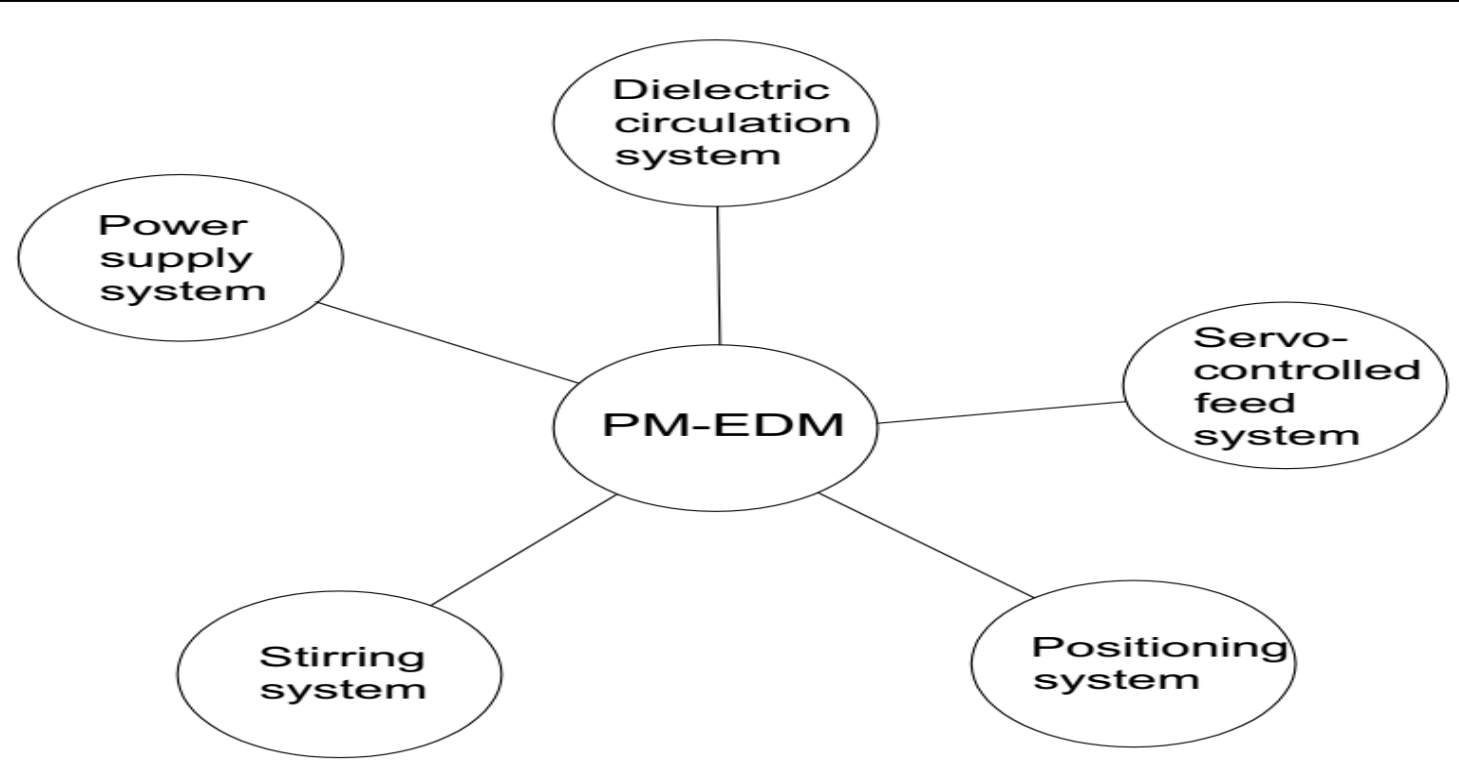

Fig. 2. Elements of PE-MDM setup (Gugulothu et al., 2015; Marashi et al., 2015; Rouniyar and Shandilya, 2019a).

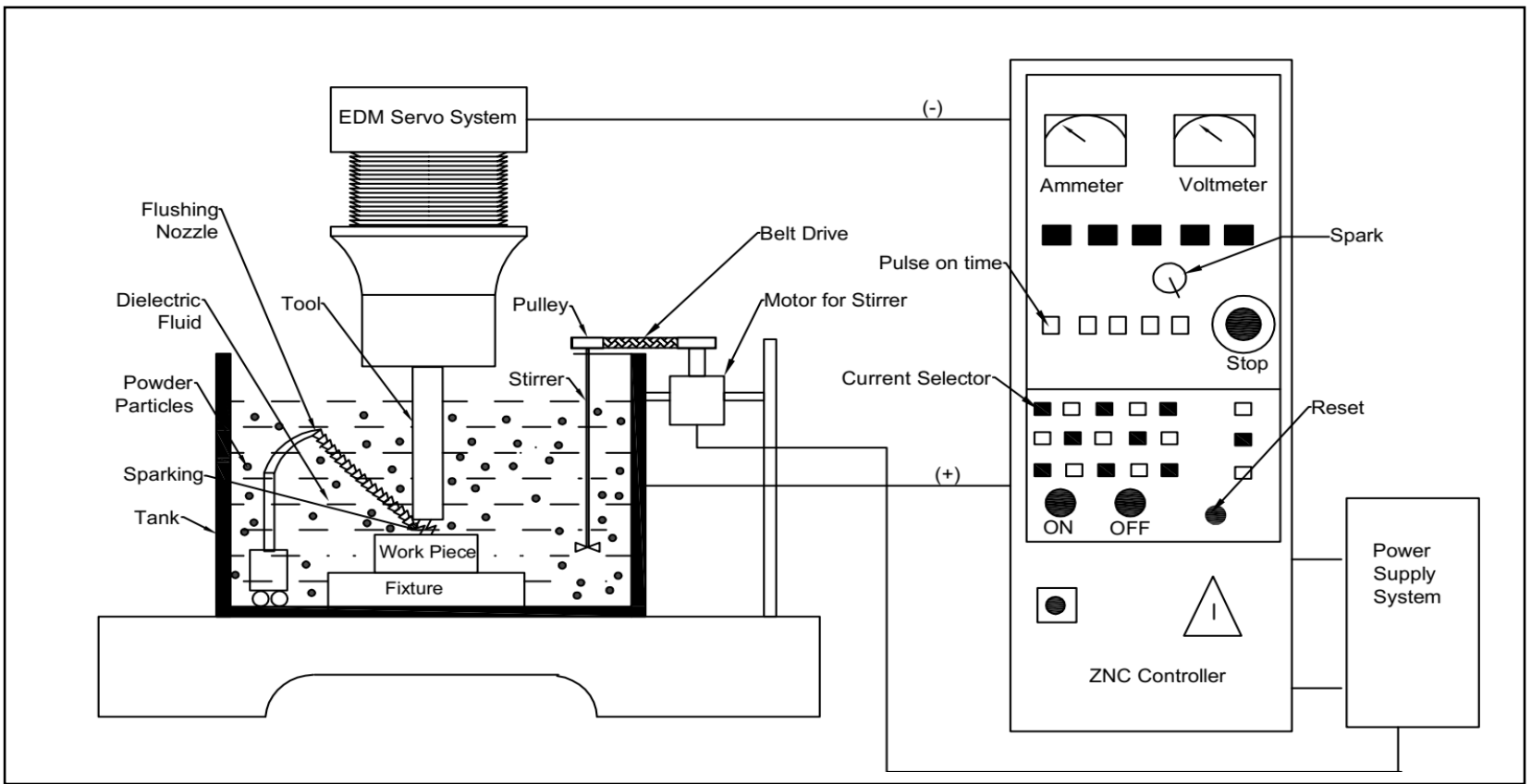

Fig. 3. Schematic diagram of PM-EDM setup (Garg and Ojha, 2012) 


\section{Major EDM Parameters}

Powder mixed EDM parameters generally consists of two categories i.e. 1) Process parameters and 2) Performance parameters.

\subsection{Process Parameters}

Process parameters in PM-EDM defines the machining conditions in which experiments are carried out. Figure 4 illustrates the classification of different types of process parameters (Choudhary and Jadoun, 2014; Gudur and Potdar, 2014; Singh and Singh, 2015, Jamadar and Kavade, 2014).

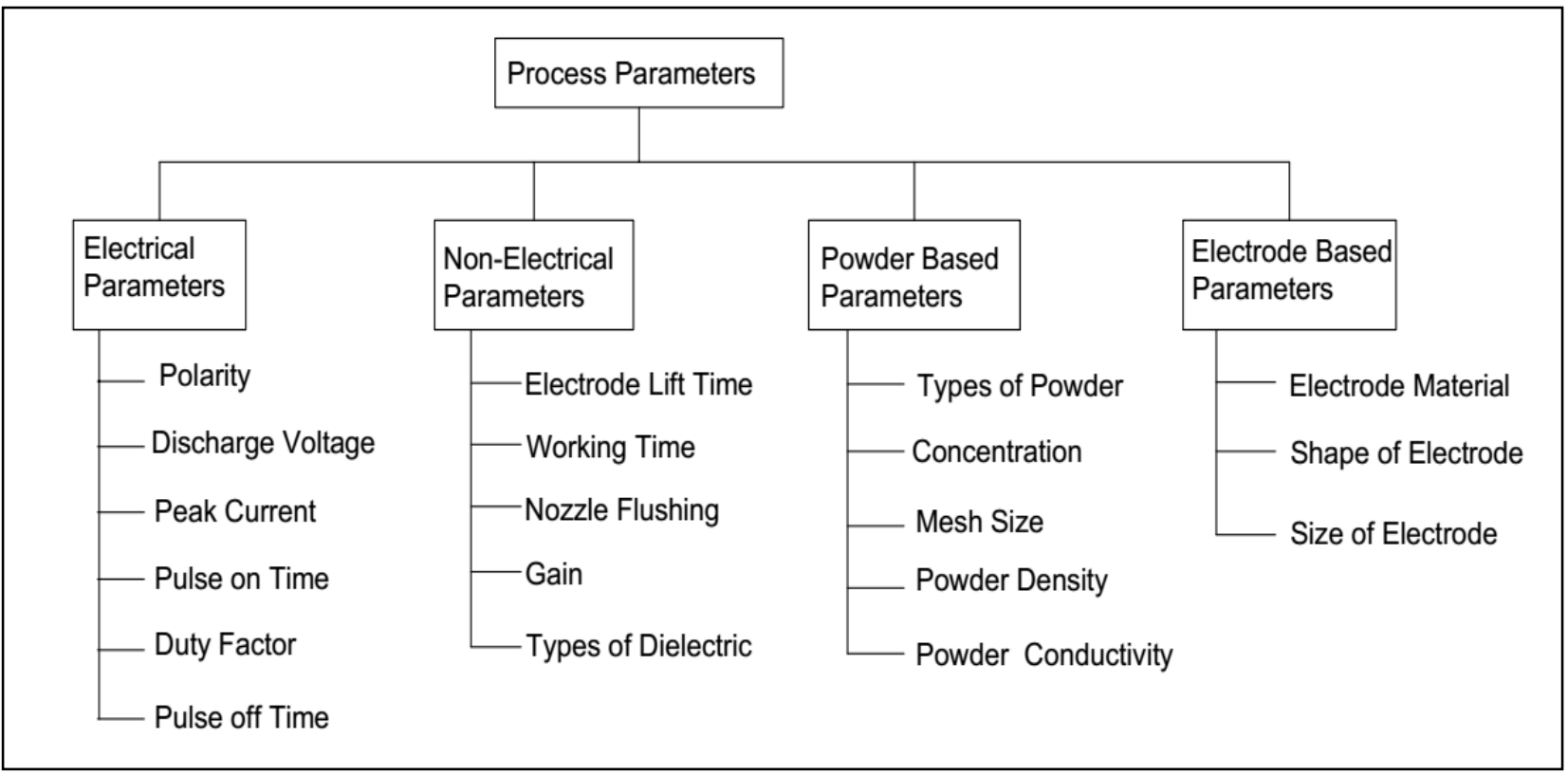

Fig. 4. Classification of process parameters

\subsection{Performance Parameters}

Performance parameters describes about the output response measure that has effect of process parameters. Figure 5 shows the classification of performance parameters (Choudhary and Jadoun, 2014; Gudur and Potdar, 2014; Singh and Singh, 2015).

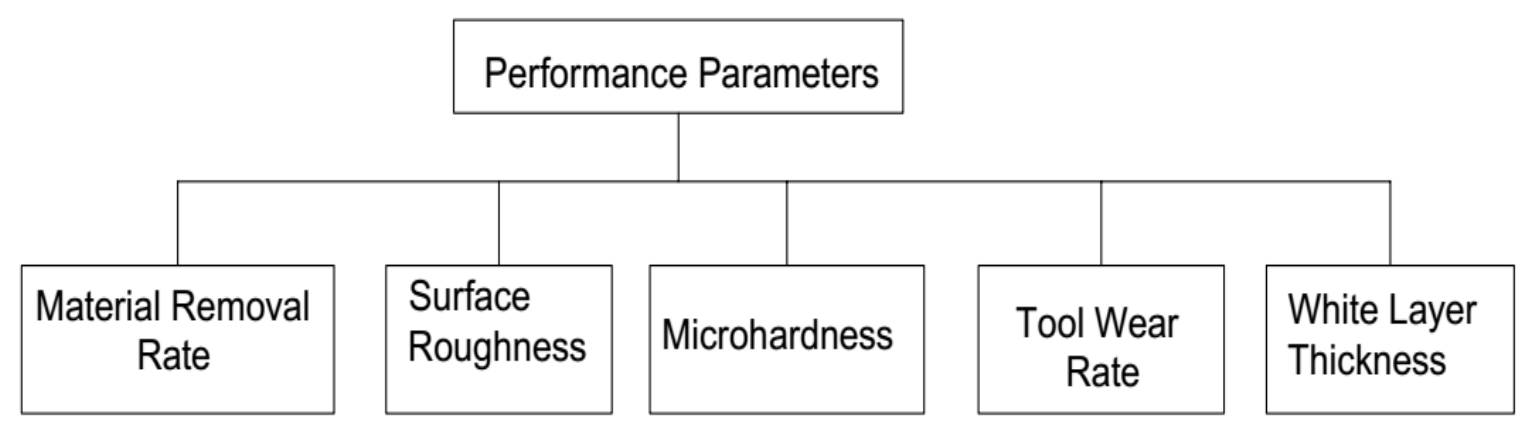

Fig. 5. Classification of performance parameters 


\section{Literature Review}

At the present prospects, the PM-EDM is well-organized hybrid EDM process widely used in industries with importance given to productivity, surface quality, and accuracy. In 1946, the application of EDM was firstly introduced in manufacturing industries for the manufacturing of dies and moulds. However, with the passage of time and technological advancement was introduced in 1954's in the EDM with variation in electrical, non-electrical and electrode based EDM process parameters. The EDM process introduced had the limitation of low material removal rate and poor surface finish.

Thus in the late 1980's, PM-EDM hybrid manufacturing process was first introduced in industries to enhance the machining rate and surface finish with the addition impurities in the form of powder in the dielectric fluid (Erden and Bilgin, 1980; Jeswani, 1981). PM-EDM process was used for machining of various conductivity materials such as die tool steels, aluminium alloy, stainless steels, Inconel, metal matrix composites, and Monel metals. Figure 6 depicts the comparative analysis in the form of the pie chart of published research work by the different researcher in the areas of PM-EDM on different materials. The effect of process parameters effect on performance characteristics have been investigated so that the required parameters can be effectively used for machining on the given materials for obtaining the desired quality level of machined components.

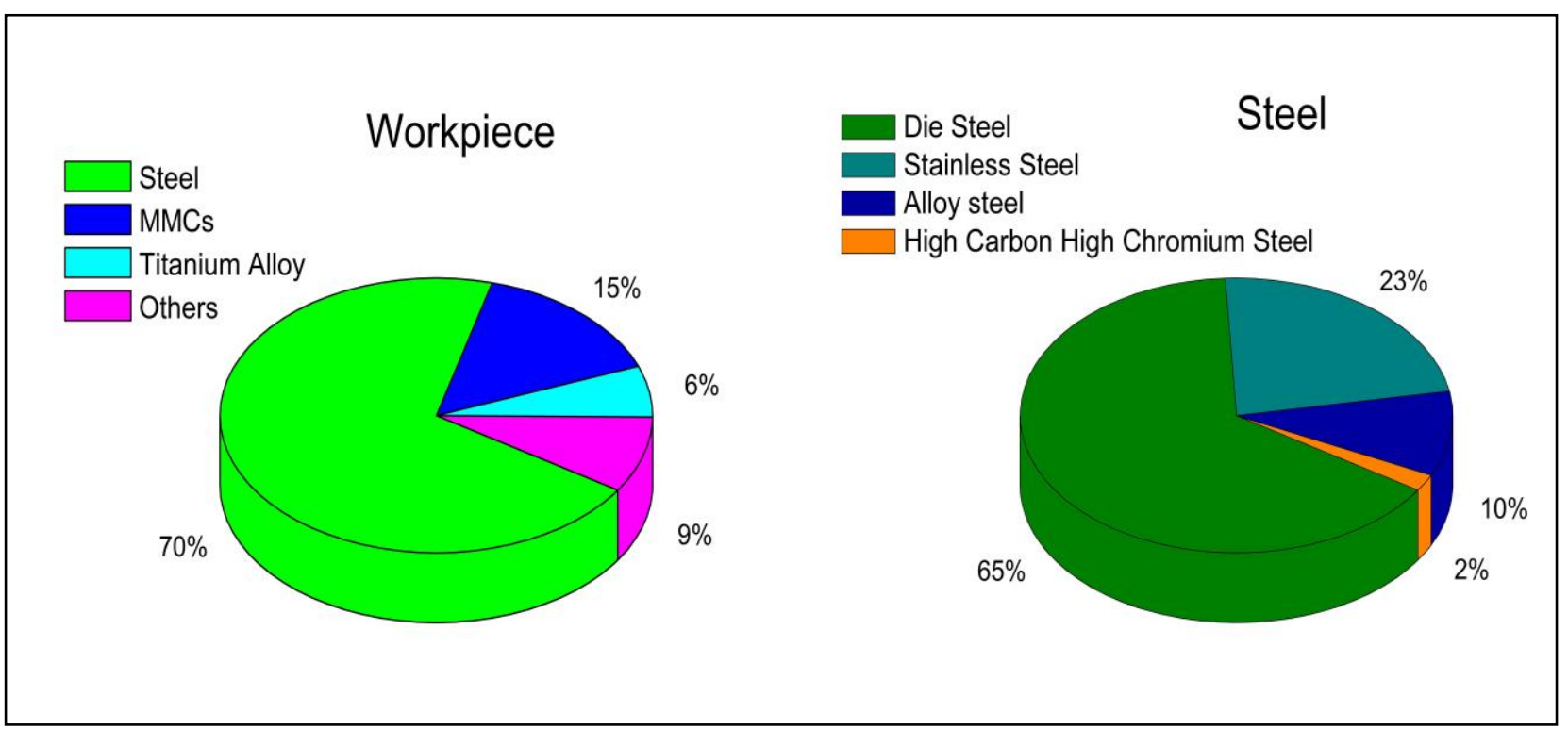

Fig. 6. Comparative analysis of research work on PM-EDM

An attempt to organise and consolidate the results of research work in the field of PM-EDM process by various researchers have been summarised in this chapter along with the future scope of research work

\subsection{PM-EDM of Steels}

Steel is an alloy of iron, which consists of carbon content ranging from $0.03 \%$ to $1.075 \%$ of its composition, depending on its grade. 
Various researchers have carried out the machining of different grades of steel such as stainless steel, die steel, alloy steel, high carbon high chromium steel, etc. Jeswani (1981) first used PM-EDM process for machining the mild steel plate using graphite as powder added in the dielectric.

At powder concentration $\left(\mathrm{P}_{\mathrm{C}}\right)$ of $4 \mathrm{~g} / \mathrm{l}, 60 \%$ improvement in material removal rate (MRR) was observed. Ming et al. (1995) used powder suspended in dielectric to carry out experiments on machining of high carbon steel through PM-EDM process. The process noticed improvement in MRR, surface roughness (SR) and tool wear ratio with addition of powder. Furutani et al. (2001) studied the accretion mechanism with titanium $(\mathrm{Ti})$ powder added to dielectric on ED machining of carbon steel.

At higher $\mathrm{P}_{\mathrm{C}}, \mathrm{TiC}$ layer was accreted using thin electrode. Tzeng and Lee (2001) investigated the effect of different types of powders to enhance the machining efficiency on machining of mould steel SKD-11. Highest MRR and lower TWR was associated with machining using chromium $(\mathrm{Cr})$ powder. Pecas and Henriques (2003, 2008) used kerosene-Castrol SE fluid 180, silicon (Si) as powder, and hardened mould steel AISI-H13 as workpiece on machining with an electrolytic copper electrode to study the influence of using different electrode and flushing flow on surface topography and roughness.

On addition of Si powder in dielectric, the surface witness improvement in the surface quality, crater depth and diameter, white layer thickness and surface heterogeneity. Figure 7 depicts the surface topography of machined samples with and without powder mixed in dielectric. Kansal et al. (2005) and Padhee et al. (2012) proposed multi-response optimization based on response surface methodology (RSM), non-dominated sorting genetic algorithm (NSGA), and grey relational analysis (GRA) to determine the optimal input parameters on ED machining EN-31 tool steel with Si powder.

Combination of high $\mathrm{I}_{\mathrm{P}}$ and $\mathrm{P}_{\mathrm{C}}$ promotes lower $\mathrm{SR}$ and higher MRR. Kansal et al. (2006) carried out machining by mixing Si powder in the dielectric on H11 steel workpiece on machining rate (MR), SR and TWR. $I_{P}$ and $P_{C}$ were most significant parameters having effect on response characteristics.

Cogun et al. (2006) machined the SAE 1040 steel with PM-EDM process and studied the influence of input parameters on SR, MRR, TWR, micro-hardness (MH), relative wear, and microstructure of machined surface. Improvement in $\mathrm{MH}$ was observed with the use of boron-based powder mixed with kerosene. Figure 8(a) \& (b) display the surface morphology and recast layer on the machining of SA1040 steel with and without powder. 


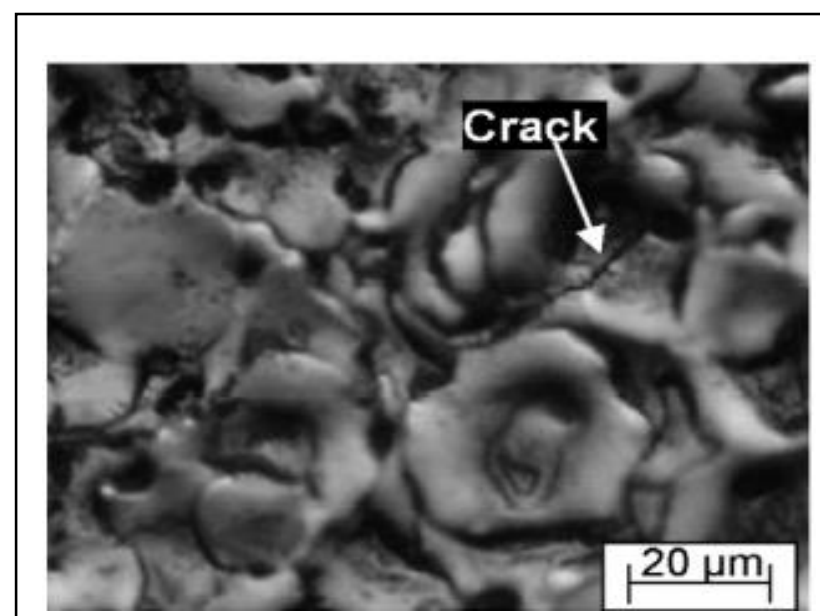

(a)

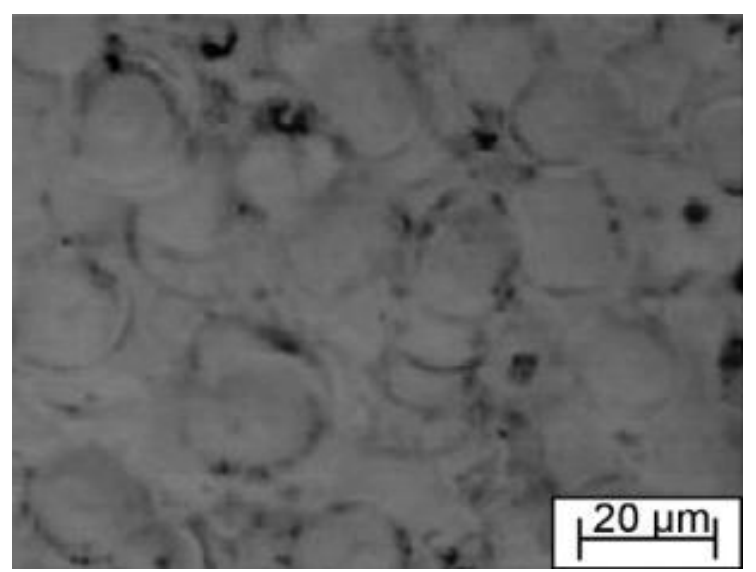

(b)

Fig. 7. Surface topography of samples machined (a) with and (b) without PMEDM conditions at $3200 \mathrm{~mm}^{2}$ electrode area (Pecas and Henriques, 2008)

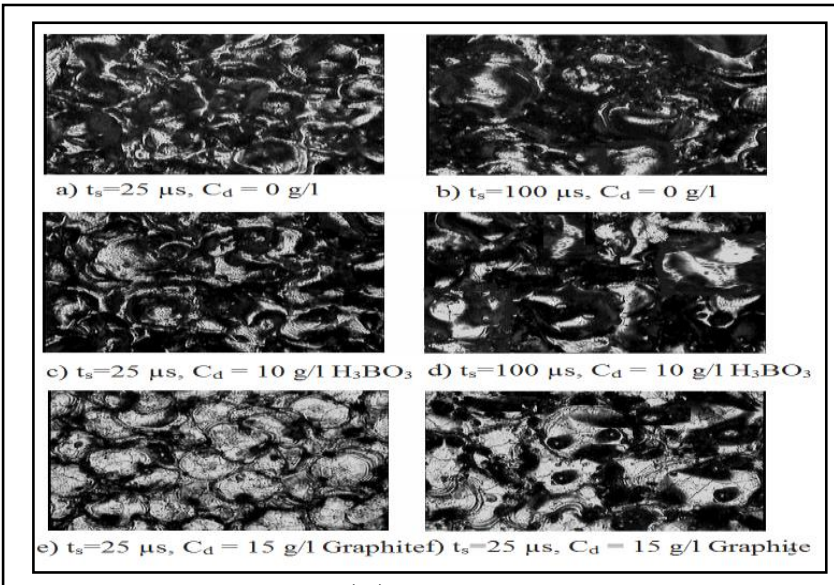

(a)

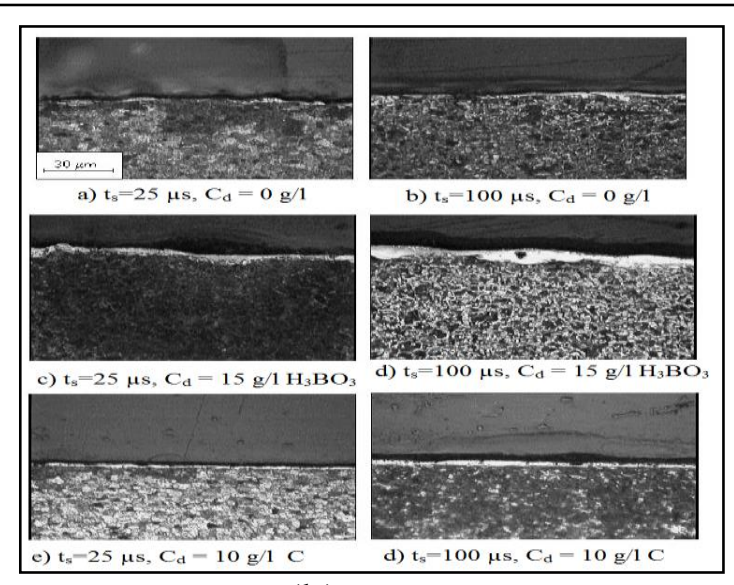

(b)

Fig. 8. (a) Surface morphology, (b) Recast layer on machined surface (Cogun et al., 2006)

Kansal et al. (2007, 2008) and Khazraji et al. (2016) performed modeling using FEM method on ANSYS software on machining of AISI D2 Die Steel using silicon powder. Influence of EDM parameters on temperature distribution, white layer thickness (WLT), MRR, heat flux and fatigue life has been studied. Powder mixed machined surface witness small and shallow craters. Sharma et al. (2010) and Singh et al. (2010) analyzed TWR, SR, percentage wear rate and MRR on machining of Hastelloy steel by mixing the aluminium (Al) powder in the dielectric fluid. On decreasing particle size of $\mathrm{Al}$ powder in dielectric improved SR, MRR, and TWR. Bhattacharya et al. (2011) and Bhattacharya et al. (2012) discussed the influence of EDM parameters on hot die steel, EN-31 steel and high carbon high chromium die steel on machining with different powder on MRR, MH, TWR and SR. Optimization was performed using Taguchi method and analytic hierarchy process. IP was most influential parameters for $\mathrm{MH}$, while kerosene produced better results than EDM oil as the dielectric fluid. Ojha et al. (2011) and Garg and Ojha (2012) machined EN-8 steel with Cr powder added to dielectric using EDM process. 
Optimum parameters for MRR, SR and TWR were performed using response surface methodology. Batish et al. (2012) studied the mechanism of material transfer and investigated the influence of EDM parameters on $\mathrm{MH}$ in machining of three different grades of die steels using graphite and Al powder mixed with a different dielectric medium through EDM.

Singh et al. (2012) and Assarzadeh and Ghoreishi (2013) developed the model to predict the SR and MRR on machining of CK45 heat-treated die steel with alumina oxide powder mixed with kerosene through EDM process. Higher value of $\mathrm{I}_{\mathrm{P}}$, lower value of pulse on time $\left(\mathrm{T}_{\mathrm{ON}}\right)$ and source voltage witness higher MRR, while at lower $\mathrm{I}_{\mathrm{P}}$ and $\mathrm{T}_{\mathrm{ON}}$ better surface finish was observed. The experiments using as silicon carbide ( $\mathrm{SiC}$ ) powder on premium stainless mold steel was carried out by Razak et al. (2015) to investigate the effect on SR, MRR and tool wear ratio. Powder mixed in dielectric improves the machining efficiency as the result of which machining time and machining cost was reduced. Multi-objective optimization was performed using TOPSIS and GRA on machining of H-11 steel for determing the optimum process parameters by Tripathy and Tripathy (2016). The optimum set of process parameters found from TOPSIS was at $\mathrm{T}_{\mathrm{ON}}=100 \mu \mathrm{s}, \mathrm{P}_{\mathrm{C}}=6 \mathrm{~g} / \mathrm{l}$, duty factor $(\tau)=90 \%$, gap voltage $(\mathrm{Vg})=50 \mathrm{~V}$ and and $\mathrm{I}_{\mathrm{P}}=6 \mathrm{~A}$ while from GRA optimum was at $\mathrm{T}_{\mathrm{ON}}=150 \mu \mathrm{s}$, $\mathrm{P}_{\mathrm{C}}=6 \mathrm{~g} / \mathrm{l}, \tau=70 \%, \mathrm{Vg}=30 \mathrm{~V}$ and $\mathrm{I}_{\mathrm{P}}=3 \mathrm{~A}$. Özerkan (2018) achieved higher $\mathrm{MH}$ on electrical discharge machined surface of AISI 1040 steel with boron oxide powder added to kerosene. Le et al. (2018) suggested improvement in SR and MH on ED machining of SKD61 with tungsten carbide (WC) suspended in EDM oil. Luzia et al. (2019) machined AISI H13 tool steel with silicion powder added in dielectic through EDM process. The effect of $I_{P}$ and $P_{O N}$ was measured on the output measures such as $\mathrm{MH}$, SR, RLT, friction coefficient, and wear resiatance. Increase in MH was observed with the formation of martensitic phase in the recast layer.

\subsection{PM-EDM of Metal Matrix Composites}

Metal matrix composites (MMCs) are particularly light weight metal alloys consisting of titanium, magnesium or aluminium reinforced with fibers/ particulate of boron oxide, graphite or silicon carbide (Bisaria and Shandilya, 2015). MMCs offers specific properties such as high operating temperature, specific stiffness, strength, better wear resistance and low thermal expansion. MMCs have been widely used in different industrial applications namely automotive engine, brake parts, missiles, aircraft, satellites, jet engine, connecting rod etc (Gibbons,1988; Shandilya et al., 2016).

Thus various researchers have carried out powder mixed ED machining of MMCs. For example, Kumar and Davim (2011) machined the Al-10\%SiCp MMCs and analyse the influence of EDM parameters on SR and MR with Si powder suspended on kerosene. The optimum settings of parameters for high MR using Taguchi method was at $\mathrm{I}_{\mathrm{P}}=9 \mathrm{~A}, \mathrm{P}_{\mathrm{C}}=4 \mathrm{~g} / \mathrm{l}, \mathrm{Vg}=50 \mathrm{~V}$ and $\mathrm{T}_{\mathrm{ON}}=100 \mu \mathrm{s}$, while for low SR was at $\mathrm{I}_{\mathrm{P}}=3 \mathrm{~A}, \mathrm{P}_{\mathrm{C}}=4 \mathrm{~g} / \mathrm{l}, \mathrm{Vg}=50 \mathrm{~V}$ and $\mathrm{T}_{\mathrm{ON}}=100 \mu \mathrm{s}$. Taguchi coupled with GRA was applied to optimize the process parameters on machining of aluminium matrix composites by Singh and Yeh (2012) for multiple responses by mixing abrasive as a powder in the dielectric fluid. 
Rouniyar, A. K. \& Shandilya, P.: Study on Powder Mixed Elecrtical Discharge Ma...

Arya et al. (2012) experimentally analyzed the effect of EDM parameters on $\mathrm{SR}$ and MRR on PM-EDM of Al-SiC MMCs using graphite powder. Emperical model for predicting the SR and MRR was developed interms of process prameters. Agrawal et al. (2013) reported that TWR on copper-iron-graphite can be reduced by $94.57 \%$ by using graphite powder added to dielectric. Artificial neural network was used to develop the predictive model for TWR and genetic algorithm used to obtain an optimum value of control factors for minimum TWR. Hu et al. (2013) machined $\mathrm{SiC}_{\mathrm{p}} / \mathrm{Al}$ composites using $\mathrm{Al}$ powder in kerosene and reported $31.5 \%$ decrease in SR and $100 \%$ increment in wear resistance.

The microstructure shown in Fig. 9 depicts cracks and pores with EDM process while smoother surface was observed with PM- EDM process. Sidhu et al. (2014) machined three different grades of MMCs by EDM on suspending different types of powder in EDM oil. XRD was performed to observe the surface integrity and microstructural analysis was performed to analyze the recast layer of the machined workpiece as shown in Fig. 10. Behera at al. (2015) focused on optimization of process parameters using Taguchi and GRA on machining of SiC reinforced ZA-27 MMCs. SR, MRR and TWR were responses considered for experimentatal work.

Talla et al. (2015) modeled the MRR and SR of PM-EDM process using dimensional and regression analysis on machining of aluminium/alumina MMCs. Optimum EDM parameters for higher MRR and lower SR were at $\mathrm{P}_{\mathrm{C}}=4 \mathrm{~g} / \mathrm{l}, \mathrm{T}_{\mathrm{ON}}=$ $150 \mu \mathrm{s}, \tau=85 \%$ and $\mathrm{I}_{\mathrm{P}}=3 \mathrm{~A}$. Prabu et al. (2015) machined Al-TiB 2 composites to determine the influence of flushing pressure, $\mathrm{T}_{\mathrm{ON}}$ and $\mathrm{I}_{\mathrm{P}}$ on MRR and TWR by mixing graphite powder on kerosene using EDM process. On increasing the $\mathrm{I}_{\mathrm{P}}$ and $\mathrm{T}_{\mathrm{ON}}$, MRR tends to increase, while decrease in TWR was reported with the use of powder in kerosene. Anuraag and Reddy (2016) observed improvement in MRR on machining $\mathrm{Al}-\mathrm{SiC}$ composite by suspending the silicon in kerosene.

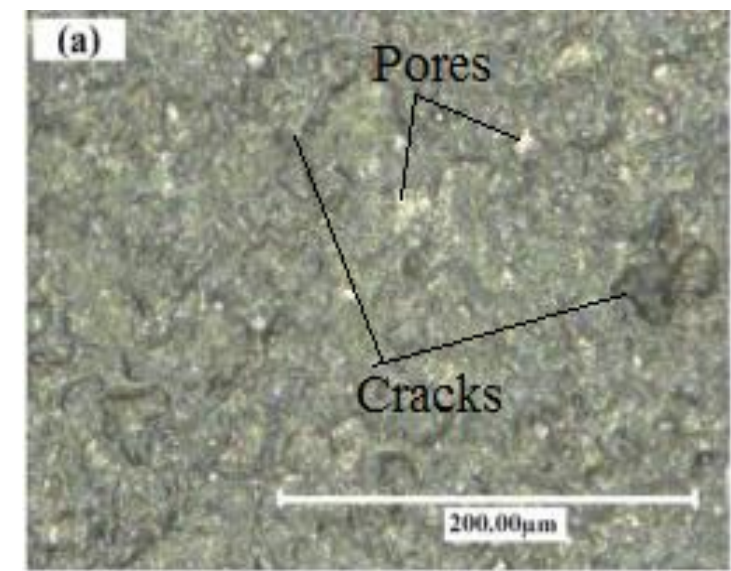

(a)

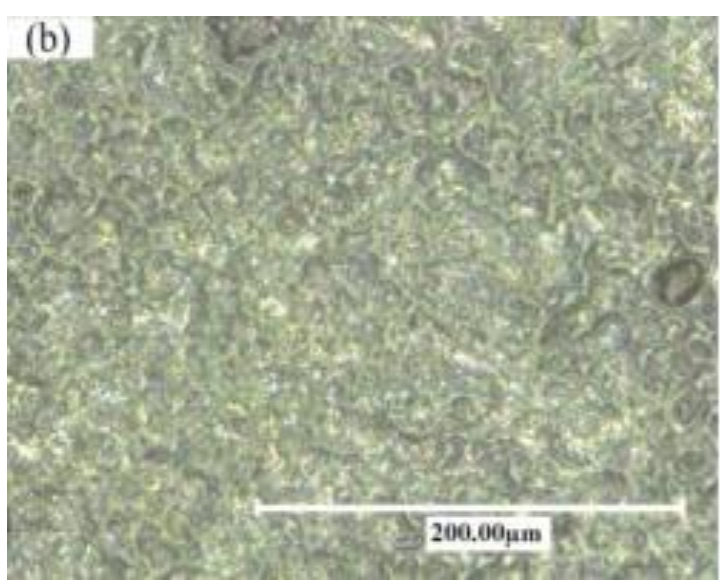

(b)

Fig. 9. Machined microstructure (a) EDM, (b) PM-EDM Process (Hu et al., 2013) 


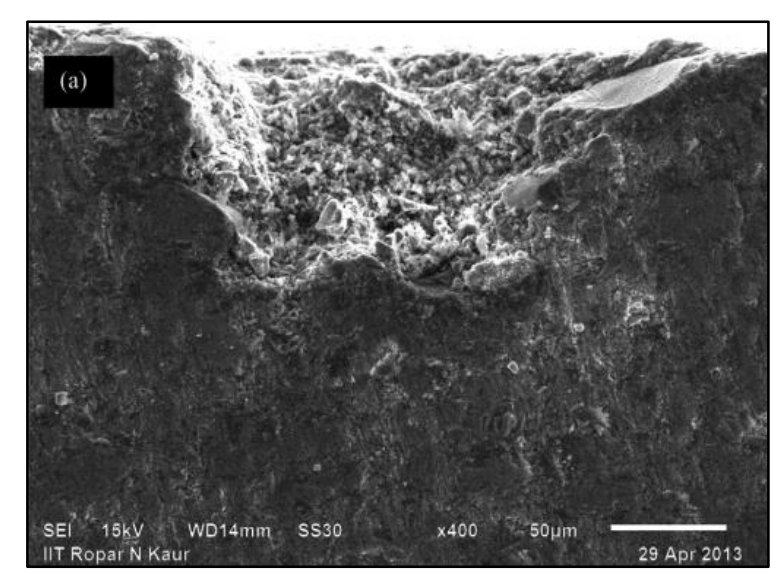

(a)

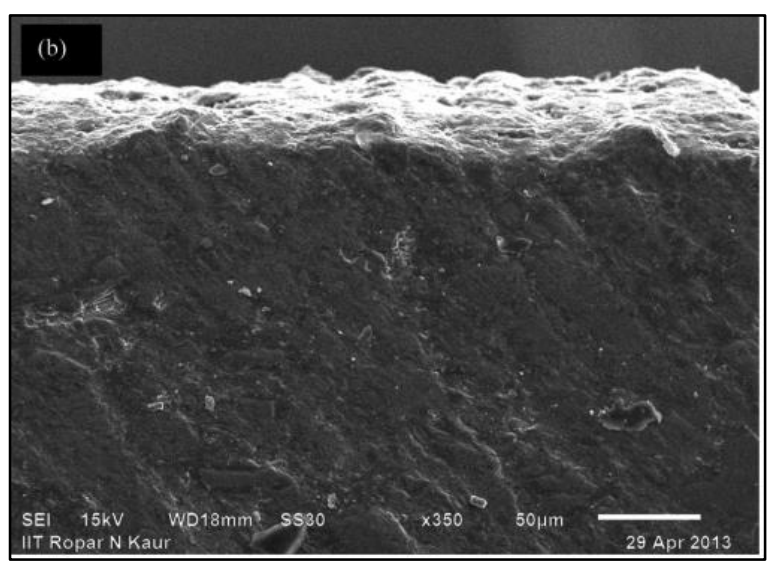

(b)

Fig. 10. SEM image of recast layer (a) Without and (b) With graphite powder mixed in dielectric (Siddhu et al., 2014)

\subsection{PM-EDM of others}

The development and technolgical advancement in society over period of time have produced various emerging materials like Inconel, nimonic, tungsten carbide, silicon carbide and super alloys which are applicable for industrial related applications. The machining of these emerging materials have been performed by researchers using PM-EDM process.

For example, Klocke at al. (2004) attempted machining of Inconel 718 and observed thinner recast layer and maximum MRR with Al powder, while grey recast layer was noticed with $\mathrm{Si}$ powder mixed in dielectric. Figure 11 shows the cross sectional view of machined area at different $\mathrm{I}_{\mathrm{P}}$ for $\mathrm{Al}$ and $\mathrm{Si}$ powder mixed in dielectric. Kung et al. (2009) machined cobalt bonded tungsten carbide with PMEDM process using Al powder in dielectric. Quadratic model was developed for predicting the MRR and electrode wear ratio. Improvement in machining efficiency of the process was observed with $\mathrm{Al}$ powder mixed in dielectric.

Jabbaripour et al. (2013) carried out ED machining of TiAl intermetallic using different powder. Improvement in MRR, SR, corrosion resistance and surface topography were observed with Al powder. Govindharajan et al. (2014) performed experiments on Monel $400^{\mathrm{TM}}$ to analyze the influence of different concentration of nickel powder combined with $6 \mathrm{~g} / \mathrm{l}$ of graphite in different dielectric on MRR and TWR. Increase in MRR by $14 \%$ and reduction in TWR by $3.16 \%$ was observed when machined in Kerosene servotherm combination as cmpareed to EDM oil and kerosene.

Kaldhone et al. (2014) observed addition of $\mathrm{Al}, \mathrm{SiC}$ and graphite powder to dielectric, increases the MRR on machining of tungsten carbide. SiC powder enhanced the MRR by $90 \%$ as compared to Al powder. Maximum MRR was observed with $\mathrm{SiC}$ at $\mathrm{P}_{\mathrm{C}}=8 \mathrm{~g} / \mathrm{l}$ and flushing pressure of $1.5 \mathrm{~kg} / \mathrm{cm}^{2}$. 
Rouniyar, A. K. \& Shandilya, P.: Study on Powder Mixed Elecrtical Discharge Ma...

Aliyu et al. (2014) used Al powder on machining of siliconized silicon carbide ( $\mathrm{SiSiC})$ and reported that $\mathrm{SR}$ and tool wear ratio had a dercreasing trend at low $\mathrm{T}_{\mathrm{ON}}$ and $I_{P}$. At high $I_{P}$ and low servo voltage, enhancement of MRR was observed.

Gugulothu et al. (2015) used graphite as powder in dielectric to improve the SR and MRR on machining Ti-6Al-4V alloy. An empirical relationship of SR and MRR with process parameters was developed using non-linear regression analysis. Kolli and Kumar (2015) implemented taguchi method to find the optimal set of parameters on ED machining of Ti-6Al-4V alloy with surfactant and graphite powder. Regression model for recast layer thickness, electrode wear rate, MRR and SR were developed.

To study the surface morphology of the machined specimen EDS and SEM was performed. Rouniyar and Shandilya (2018) machined Inconel-718 with use of graphite powder mixed in EDM oil with EDM process. Multi-objective optimization was carried out using GRA to determine maximum MRR and minium SR. Ramesh and Jenarthanan (2018) tried addition of Al powder in EDM oil to machine the Nimonic 75 through EDM process and found improvement in SR and TWR.

Sahu et al. (2019) reported increase in MRR and improvement in SR by $19 \%$ and $11 \%$, respectively on machining of Inconel 825 with alumina powder suspended in EDM oil through EDM process. Surface morphology shown in Fig. 12 witness smaller crack, voids, and craters on the machined surface of PM-EDM as compared to conventional EDM process.

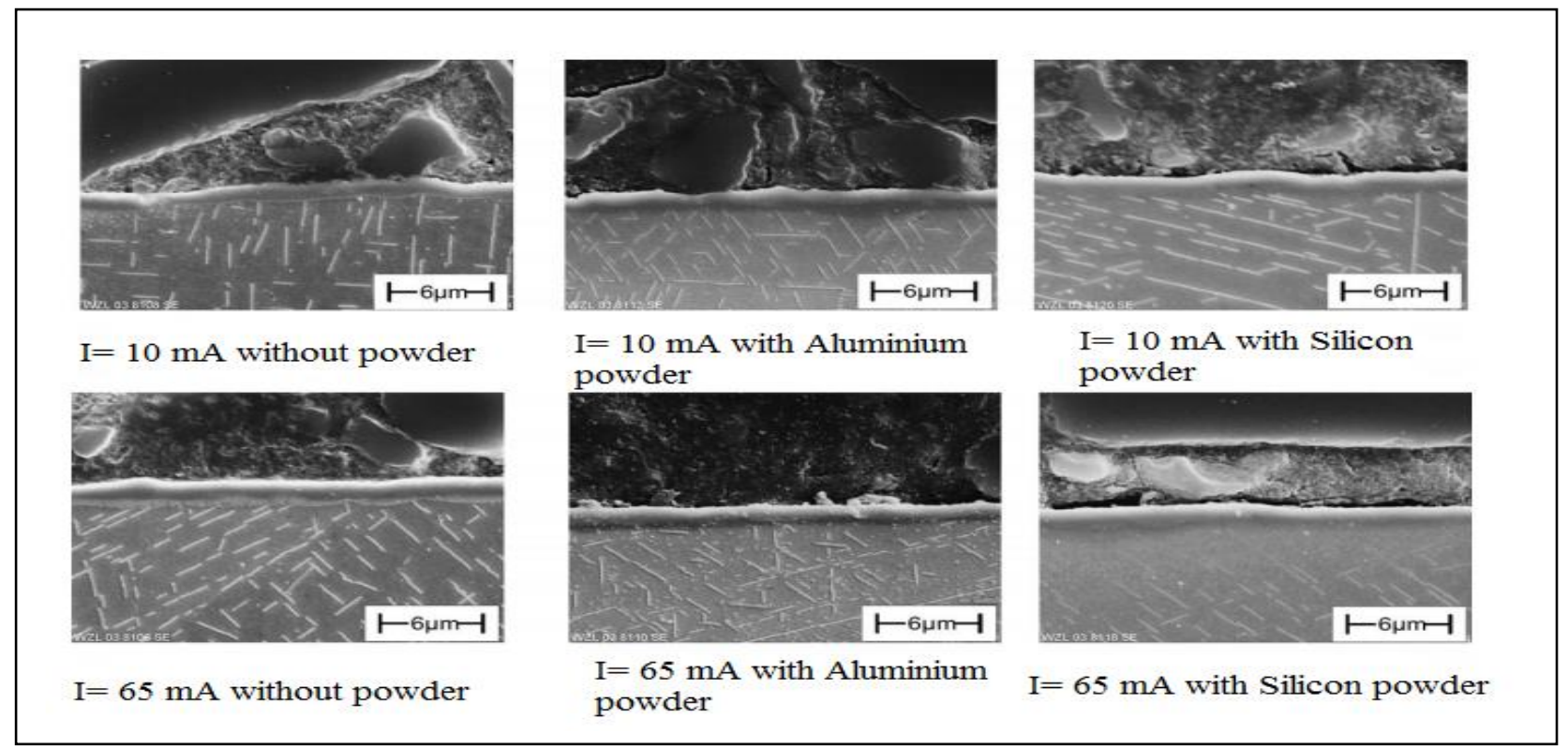

Fig. 11. Cross sectional view of machined area without powder, with $\mathrm{Al}$ powder and Si powder (Klocke at al., 2004) 


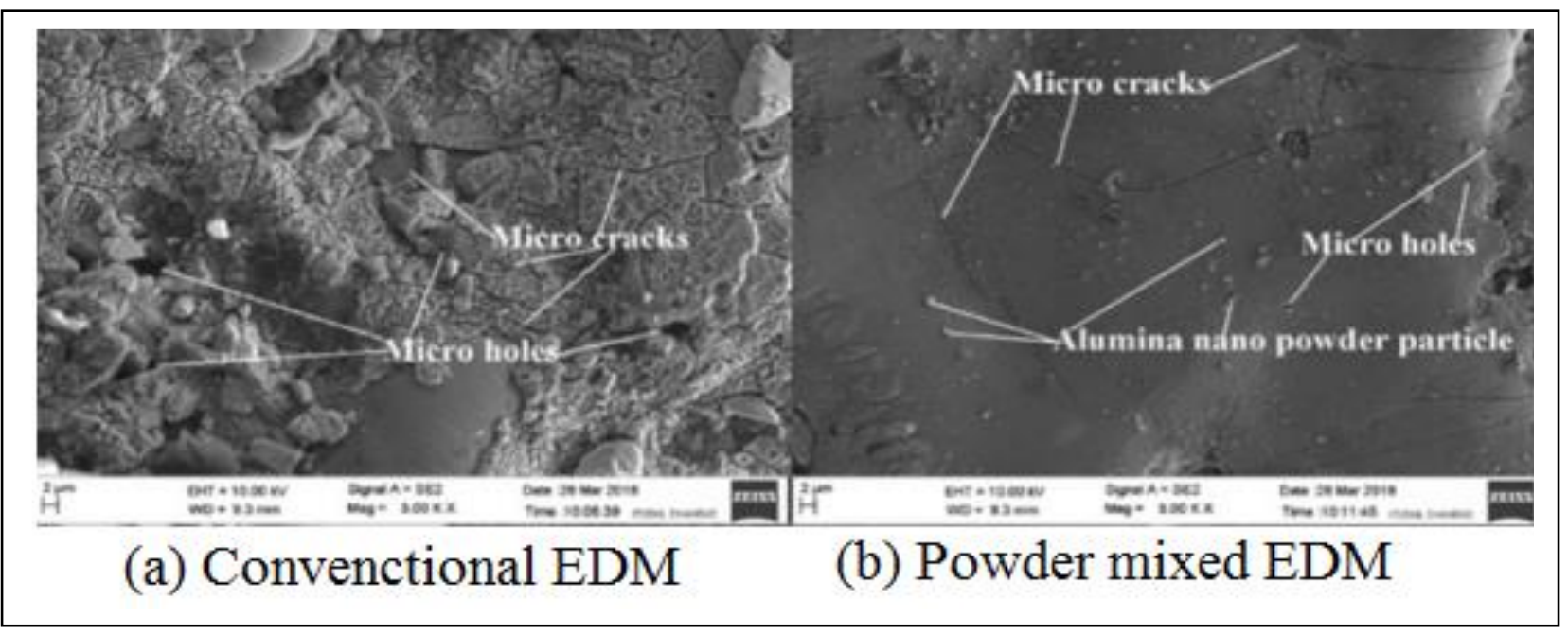

Fig. 12. Surface morphology of machining using (a) Convectional EDM (b) PMEDM process (Sahu et al., 2019)

\section{Comments for Literature Review}

The research work performed by worldwide researchers in the area of machining though PM-EDM is summarized in Table 1.

\begin{tabular}{|c|c|c|c|c|c|}
\hline Author(s) & $\begin{array}{l}\text { Investigation } \\
\text { on }\end{array}$ & $\begin{array}{l}\text { Process } \\
\text { Parameter }\end{array}$ & $\begin{array}{l}\text { Workpiece } \\
\text { Material }\end{array}$ & Powder & Dielectric \\
\hline $\begin{array}{l}\text { Jeswani } \\
\text { (1981) }\end{array}$ & MRR & $\mathrm{P}_{\mathrm{C}}$ & Mild steel & Graphite & EDM oil \\
\hline $\begin{array}{l}\text { Ming et al. } \\
\text { (1995) }\end{array}$ & MRR and SR & $\mathrm{I}_{\mathrm{P}}, \mathrm{T}_{\mathrm{ON}}$ & $\begin{array}{l}\text { High carbon } \\
\text { steel }\end{array}$ & $\begin{array}{l}\text { lipophili } \\
\text { c surface } \\
\text { agent }\end{array}$ & Kerosene \\
\hline $\begin{array}{l}\text { Klocke at al. } \\
(2004)\end{array}$ & $\begin{array}{l}\text { Recast layer } \\
\text { and MRR }\end{array}$ & $\mathrm{I}_{\mathrm{P}}, \mathrm{P}_{\mathrm{C}}$ & Inconel 718 & $\mathrm{Al}, \mathrm{Si}$ & $\begin{array}{l}\text { Oel Held } \\
\text { IME } 63 \text { oil }\end{array}$ \\
\hline $\begin{array}{l}\text { Kansal et al. } \\
(2006)\end{array}$ & $\begin{array}{l}\text { MR, SR and } \\
\text { TWR }\end{array}$ & $\begin{array}{lll}\mathrm{I}_{\mathrm{P}}, & \tau, & \mathrm{P}_{\mathrm{C}}, \\
\mathrm{T}_{\mathrm{ON}}\end{array}$ & H11 steel & $\mathrm{Si}$ & EDM oil \\
\hline $\begin{array}{l}\text { Cogun et al. } \\
(2006)\end{array}$ & $\begin{array}{l}\text { SR, MRR, } \\
\text { TWR and MH }\end{array}$ & $\mathrm{P}_{\mathrm{C}}, \mathrm{T}_{\mathrm{ON}}$ & $\begin{array}{ll}\text { SAE } & 1040 \\
\text { steel } & \end{array}$ & $\begin{array}{l}\text { Graphite, } \\
\text { boric } \\
\text { acid }\end{array}$ & Kerosene \\
\hline $\begin{array}{l}\text { Pecas and } \\
\text { Henriques } \\
(2008)\end{array}$ & $\begin{array}{l}\text { SR and Surface } \\
\text { Topography }\end{array}$ & $\begin{array}{l}\mathrm{I}_{\mathrm{P}}, \quad \tau, \quad \mathrm{P}_{\mathrm{C}}, \\
\text { Polarity }\end{array}$ & $\begin{array}{l}\text { Hardened } \\
\text { mould steel } \\
\text { AISI-H13 }\end{array}$ & $\mathrm{Si}$ & $\begin{array}{l}\text { Kerosene- } \\
\text { Castrol SE } \\
\text { fluid } 180\end{array}$ \\
\hline $\begin{array}{l}\text { Kung et al. } \\
(2009)\end{array}$ & $\begin{array}{l}\text { MRR and } \\
\text { Electrode wear } \\
\text { ratio }\end{array}$ & $\begin{array}{l}\mathrm{I}_{\mathrm{P}}, \mathrm{P}_{\mathrm{C}}, \mathrm{T}_{\mathrm{ON}} \\
\text { and grain } \\
\text { size }\end{array}$ & $\begin{array}{l}\text { Cobalt } \\
\text { bonded } \\
\text { tungsten } \\
\text { carbide }\end{array}$ & $\mathrm{Al}$ & $\begin{array}{l}\text { Commercia } \\
\text { l-grade } \\
\text { mineral oil }\end{array}$ \\
\hline $\begin{array}{l}\text { Kumar and } \\
\text { Davim } \\
\text { (2011) }\end{array}$ & SR and MR & $\begin{array}{l}\mathrm{I}_{\mathrm{P}}, \mathrm{P}_{\mathrm{C}}, \mathrm{T}_{\mathrm{ON}} \text {, } \\
\text { and } \mathrm{Vg}\end{array}$ & $\begin{array}{l}\text { Al-10\%SiCp } \\
\text { MMCs }\end{array}$ & $\mathrm{Si}$ & Kerosene \\
\hline
\end{tabular}


Rouniyar, A. K. \& Shandilya, P.: Study on Powder Mixed Elecrtical Discharge Ma...

\begin{tabular}{|c|c|c|c|c|c|}
\hline $\begin{array}{l}\mathrm{Hu} \text { et al. } \\
(2013)\end{array}$ & $\begin{array}{l}\text { Wear } \\
\text { resistance and } \\
\text { SR }\end{array}$ & $\mathrm{I}_{\mathrm{P}}, \mathrm{P}_{\mathrm{C}}$ & $\begin{array}{l}\mathrm{SiCp} / \mathrm{Al} \\
\text { composites }\end{array}$ & $\mathrm{Al}$ & kerosene \\
\hline $\begin{array}{l}\text { Govindharaj } \\
\text { an et al. } \\
\text { (2014) }\end{array}$ & $\begin{array}{ll}\text { MRR and } \\
\text { TWR }\end{array}$ & $\mathrm{P}_{\mathrm{C}}$ & $\begin{array}{l}\text { Monel } \\
\text { 400TM }\end{array}$ & $\begin{array}{l}\text { Nickel, } \\
\text { Graphite }\end{array}$ & $\begin{array}{l}\text { Kerosene, } \\
\text { EDM oil }\end{array}$ \\
\hline $\begin{array}{l}\text { Kolli and } \\
\text { Kumar } \\
(2015)\end{array}$ & $\begin{array}{lr}\text { MRR, } & \text { SR, } \\
\text { RLT, and } \\
\text { electrode } & \text { wear } \\
\text { rate }\end{array}$ & $\begin{array}{l}\mathrm{I}_{\mathrm{P}}, \quad \mathrm{P}_{\mathrm{C}}, \\
\text { Surfactant } \\
\text { conc. }\end{array}$ & $\begin{array}{l}\text { Titanium } \\
\text { alloy }\end{array}$ & $\begin{array}{l}\text { surfactan } \\
\mathrm{t} \text { and } \\
\text { graphite }\end{array}$ & EDM oil \\
\hline $\begin{array}{l}\text { Khazraji et } \\
\text { al. (2016) }\end{array}$ & $\begin{array}{l}\text { WLT, heat } \\
\text { flux, MRR, } \\
\text { fatigue life and } \\
\text { temperature } \\
\text { distribution, }\end{array}$ & $\begin{array}{l}\mathrm{I}_{\mathrm{P}}, \mathrm{T}_{\mathrm{ON}}, \mathrm{P}_{\mathrm{C}}, \\
\mathrm{T}_{\mathrm{OFF}}\end{array}$ & $\begin{array}{l}\text { AISI D2 Die } \\
\text { Steel }\end{array}$ & $\mathrm{Si}$ & Kerosene \\
\hline $\begin{array}{l}\text { Ozerkan } \\
(2018)\end{array}$ & $\begin{array}{l}\mathrm{MH} \quad \text { and } \\
\text { microstructure }\end{array}$ & $\begin{array}{lr}\mathrm{T}_{\mathrm{ON}}, & \mathrm{P}_{\mathrm{C}}, \\
\text { types } & \text { of } \\
\text { powder } & \end{array}$ & $\begin{array}{ll}\text { AISI } & 1040 \\
\text { steel } & \end{array}$ & $\begin{array}{l}\text { Boron } \\
\text { oxide }\end{array}$ & Kerosene \\
\hline $\begin{array}{l}\text { Ramesh and } \\
\text { Jenarthanan } \\
\text { (2018) }\end{array}$ & $\begin{array}{ll}\text { MRR, } & \text { TWR } \\
\text { and SR } & \end{array}$ & $\mathrm{I}_{\mathrm{P}}, \mathrm{T}_{\mathrm{ON}}, \mathrm{P}_{\mathrm{C}}$ & $\begin{array}{l}\text { Nimonic-75 } \\
\text { and AISI } \\
\text { P20 steel }\end{array}$ & $\mathrm{Al}$ & Kerosene \\
\hline $\begin{array}{l}\text { Le et al. } \\
(2018)\end{array}$ & SR and $\mathrm{MH}$ & $\mathrm{I}_{\mathrm{P}}, \mathrm{T}_{\mathrm{ON}}, \mathrm{P}_{\mathrm{C}}$ & SKD61 Steel & WC & $\begin{array}{ll}\text { Shell } & \text { Oil } \\
\text { EDM } & \end{array}$ \\
\hline $\begin{array}{l}\text { Luzia et al. } \\
(2019)\end{array}$ & $\begin{array}{ll}\text { Wear } & \\
\text { resistance, SR, } \\
\text { RLT and } \\
\text { Friction } \\
\text { coefficient } \\
\end{array}$ & $\begin{array}{l}\mathrm{I}_{\mathrm{P}}, \mathrm{T}_{\mathrm{ON}}, \\
\text { Machining } \\
\text { time }\end{array}$ & $\begin{array}{l}\text { AISI H13 } \\
\text { tool steel }\end{array}$ & $\mathrm{Si}$ & $\begin{array}{l}\text { Deionized } \\
\text { water }\end{array}$ \\
\hline $\begin{array}{l}\text { Sahu et al. } \\
(2019)\end{array}$ & $\mathrm{MRR}, \mathrm{SR}$ & $\mathrm{T}_{\mathrm{ON}}, \mathrm{I}_{\mathrm{P}}, \mathrm{V}_{\mathrm{g}}$ & Inconel 825 & $\mathrm{Al}_{2} \mathrm{O}_{3}$ & EDM oil \\
\hline
\end{tabular}

Tab. 1. Summary on literature review on machining using PM-EDM process

\section{Summary}

This book chapter focussed on PM-EDM of hard and conductive materials such as ceramics, metal matrix composites, hardened steel and super alloys that are difficult to machine by conventional and other advanced machining process. The applications of PM-EDM can be seen different industries involving in the manufacturing of various components namely automobile parts, dies, surgical instruments, military parts, and aerospace components. PM-EDM process has addressed the problem of lower machining rate and poor surface quality that arises in the conventional EDM process. 
It was observed that most of the researchers have chosen the process parameters such as pulse on time, peak current, powder concentration, pulse off time for finding their effects on performance characteristics namely material removal rate, surface roughness, microhardness, recast layer and tool wear rate in PM-EDM. Improvement in surface integrity aspects namely SR, RLT, MH, and surface topography were observed by addition of required amount of fine powder in EDM oil as dielectric fluid. Peak current, pulse on time, and powder concentration were observed as most significant process parameters on machining of conductive materials. Machined surface witness presence of smaller globular debris particles, voids, and micro-cracks as compared to machining with conventional EDM process. Most of the researchers used Taguchi and RSM for designing the experiments, analysing, and optimizing the experimental results. The soft computing techniques namely grey relational analysis, genetic algorithm, etc. were also considered by few researchers for optimizing the experimental results for multi-response optimization to obtain desired quality of components.

\section{Future Scope}

Though the various researchers have contributes to improve cutting performance of PM-EDM of advanced materials, yet the following work can be done in future -

1. The hard and conductive materials such as molybdenum, high speed tool steels, OHNS die steel, Inconel, intermetallic alloy might be machined with different shape of electrode to create intricate profiles.

2. The effects of different powders such as manganese, chromium, molybdenum, vanadium, titanium and zirconium powder on machining of advanced materials are still unrevealed.

3. The advanced soft computing techniques can be utilized to enhance the process capability of PM-EDM parameters and reduce the error in the experimental results.

\section{References}

Agrawal, A.; Dubey, A.K. \& Shrivastava, P.K. (2013). Modeling and optimization of tool wear rate in powder mixed EDM of MMC. 2nd International Conference on Mechanical and Robotics Engineering, 1-6.

Aliyu, A.; Musa, H. \& Rohani, J.M. (2014). Parametric study of powder mixed electrical discharge machining and mathematical modeling of SiSiC using copper electrode. Advanced Materials Research, 845, 878-882.

Anuraag, G.P. \& Reddy, M.V.K. (2016). Studies on the material removal rate of Al$\mathrm{SiC}$ composites machined by powder mixed EDM technique. International Journal of Engineering and Technology, 8(2), 829-836.

Arya, R.K.; Dvivedi, A. \& Karunakar, D.B. (2012). Parametric investigation of powder mixed electrical discharge machining of $\mathrm{Al}-\mathrm{SiC}$ metal matrix composites. International Journal of Engineering Innovation \& Research, 1(6), 559-566. 
Assarzadeh, S. \& Ghoreishi, M. (2013). A dual response surface-desirability approach to process modeling and optimization of $\mathrm{Al} 2 \mathrm{O} 3$ powder mixed electrical discharge machining (PM-EDM) parameters. International Journal of Advance Manufacturing Technology, 64, 1459-1477.

Batish, A.; Bhattacharya, A.; Singla, V.K. \& Singh, G. (2012). Study of material transfer mechanism in die steelsusing powder mixed electric discharge machining. Materials and Manufacturing Processes, 27, 449-456.

Behera, S.; Satapathy, S. \& Ghadai, S.K. (2015). Parameter optimization of powder mixed EDM ofaluminium based metal matrix composite usingtaguchi and grey analysis. International Journal of Productivity and Quality Management, 16(2), 148168.

Bhattacharya, A.; Batish, A. \& Singh, G. (2011). Optimization of powder mixed electric discharge machining using dummy treated experimental design with analytic hierarchy process. Proceedings of the Institution of Mechanical Engineers 226, Part B: Journal Engineering Manufacture, 103-116.

Bhattacharya, A.; Batish, A. \& Singh, G. (2012). Surface modification of high carbon high chromium, EN31 and hot die steel using powder mixed EDM process.Materials Science Forum, 701, 43-59.

Bisaria, H. \& Shandilya, P. (2015). Machining of metal matrix composites by EDM and its Variants: A Review.DAAAM International Scientific Book, 23, 267-282.

Choudhary, S.K. \& Jadoun R.S. (2014). Current research issue, trend \& applications of powder mixed dielectric electric discharge machining (PMEDM): A review. International Journal of Engineering Sciences \& Research Technology, 3(7), 335358.

Cogun, C.; Ozerkan, B. \& Karacay, T. (2006). An experimental investigation on the effect of powder mixed dielectric on machining performance in electric discharge machining. Proceedings of the Institution of Mechanical Engineers 220, Part B: Journal of Engineering Manufacture, 1035-1050.

Ekmekci, B.; Yaşar, H. \& Ekmekci, N. (2016). A Discharge Separation Model for Powder Mixed Electrical Discharge Machining. ASME. Journal of Manufacturing Science and Engineeering 2016;138(8):081006-081006-9. doi:10.1115/1.4033042.

Erden, A. \& Bilgin, S. (1980).Role of impurities in electrical discharge machining. Proceedings of International Machine Tool Design and Research Conference, London, 345-350.

Furutania, K.; Sanetoa, A.; Takezawaa, H.; Mohria, N. \& Miyake, H. (2001) Accretion of titanium carbide by electrical discharge machining with powder suspended in working fluid. Journal of the International Societies for Precision Engineering and Nanotechnology, 25, 138-144.

Garg, R.K. \& Ojha, K. (2012), Parametric optimization of PM-EDM process with chromium powder suspended dielectric for minimum surface roughness and maximum MRR. Advanced Materials Research, 383-390, 3202-3206.

Gibbons, J.H (1988). Metal Matrix Composites. Advanced Materials by Design, chapter 4, 99-120. 
Govindharajan, B.; Meivel, P.; Chelladurai, C. \& Avinaash, K. (2014). Performance and analysis of nickel mixed kerosene servotherm in EDM of Monel 400TM. Journal of Innovative Research and Solution, 1(1), 348-354.

Gudur, S. \& Potdar, V.V. (2014). A review on effect of aluminum \& silicon powder mixed EDM on response variables of various materials. International Journal of Innovative Research in Science, Engineering and Technology, 3(12), 17937-17945. Gugulothu, B.;Rao, D.H. \& Rao, G.K.M. (2015). Optimization of EDM process parameters andgraphite powder concentration on electricaldischarge machining of Ti6Al-4V alloy using Taguchi method. International Journal of Advances in Production and Mechanical Engineering, 1, 31-44.

Hu, F.Q.; Cao, F.Y.; Song, B.Y.; Hou, P.J.; Zhang, Y.; Chen, K. and Wei, J.Q. (2013). Surface Properties of SiCp/Al Composite by Powder Mixed EDM. The Seventeenth CIRP Conference on Electro Physical and Chemical Machining (ISEM), 101-106.

Jabbaripour, B.; Sadeghi, M.H.; Shabgard, M.R. \& Faraji, H. (2013). Investigating surface roughness, material removal rate and corrosion resistance in PM-EDM of Ti$\mathrm{Al}$ intermetallic. Journal of Manufacturing Processes, 15, 56-68.

Jamadar, M.M. \& Kavade, M.V. (2014). Effect of aluminium powder mixed EDM on machining characteristics of die steel (AISI-D3). International Journal of Mechanical and Production Engineering, 2(8), 25-28.

Jeswani, M.L. (1981). Effect of the addition of graphite powder to kerosene used as the dielectric fluid in electrical discharge machining. Wear, 70, 133-139.

Kaldhone, S.Y., Kavade, M.V. \& Rawat, U. (2014). Effect of powder mixed dielectric on performance measures of EDM for tungsten carbide. International Journal of Innovative Research in Advanced Engineering, 1(10),109-111.

Kansal, H.K.; Singh, S. \& Kumar, P. (2005). Parametric optimization of powder mixed electrical discharge machining by response surface methodology. Journal of Materials Processing Technology, 169, 427-436.

Kansal, H.K.; Singh, S. \& Kumar, P. (2006). Performance parameters optimization (multi-characteristics) of powder mixed electric discharge machining (PM-EDM) through Taguchi's method and utility concept. Indian Journal of Engineering and Material Science, 13, 209-216

Kansal, H.K.; Singh, S. \& Kumar, P. (2007). Effect of silicon powder mixed EDM on machining rate of AISI D2 die steel. Journal of Manufacturing Processes, 9(1), 13-22. Kansal, H.K.; Singh, S. \& Kumar, P. (2008). Numerical simulation of powder mixed electric discharge machining (PM-EDM) using finite element method. Mathematical and Computer Modelling, 47, 1217-1237.

Khazraji, A.; Amin, S.A. \& Ali, S.M. (2016). The effect of SiC powder mixing electrical discharge machining on white layer thickness, heat flux and fatigue life of AISI D2 die steel. Engineering Science and Technology, an International Journal, 19, 1400-1415.

Klocke, F.; Lung, D.; Antonoglou, G. \& Thomaidis, D. (2004). The effects of powder suspended dielectrics on the thermal influenced zone by electro discharge machining with small discharge energies. Journal of Materials Processing Technology, 149, 191197. 
Kolli, M. \& Kumar, A. (2015). Effect of dielectric fluid with surfactant and graphite powder on electrical discharge machining of titanium alloy using taguchi method. Engineering Science and Technology, an International Journal, 18, 524-535.

Kumar, S. \& Singh, R. (2010). Investigating surface properties of OHNS die steel after electrical discharge machining with manganese powder mixed in the dielectric. International Journal of Advance Manufacturing Technology, 50, 625-633.

Kumar, A.; Maheshwari, S.; Sharma, C. \& Beri, N. (2011). Analysis of machining characteristics in additive mixed electric discharge machining of nickel-based super alloy Inconel 718. Materials and Manufacturing Processes, 26, 1011-1018.

Kumar, H. \& Davim, J.P. (2011). Role of powder in the machining of Al 10\% SiCp metal matrix composites by powder mixed electric discharge machining. Journal of Composite Materials, 45(2), 133-150.

Kung, K.Y.; Horng, J.T. \& Chiang, K.T. (2009). Material removal rate and electrode wear ratio study on the powder mixed electrical discharge machining of cobaltbonded tungsten carbide. International Journal of Advanced Manufacturing Technology, 40, 95-104.

Luzia, C.A.O.; Laurindo, C.A.H.; Soares, P.C.; Torres, R.D., Mendes, L.A., \& Amorim, F.L. (2019). Recast layer mechanical properties of tool steel after electrical discharge machining with silicon powder in the dielectric. The International Journal of Advanced Manufacturing Technology. doi:10.1007/s00170-019-03549-w

Marashi, H.; Sarhan, A.A.D. \& Hamdi, M. (2015). Employing Ti nano-powder dielectric to enhance surface characteristics in electrical discharge machining of AISI D2 steel. Applied Surface Science, 357,892-907.

Ming, Q.Y. \& He, L.Y. (1995). Powder-suspension dielectric fluid for EDM. Journal of materials processing technology, 52, 44-54.

Ojha, K.; Garg, R.K. \& Singh, K.K. (2011). Parametric optimization of PM-EDM process using chromium powder mixed dielectric and triangular shape electrodes. Journal of Minerals \& Materials Characterization \& Engineering, 10(11), 1087-1102. Özerkan, H.B. (2018). Simultaneous machining and surface alloying of AISI 1040 steel by electrical discharge machining with boron oxide powders. Journal of Mechanical Science and Technology, 32(9), 4357-4364.

Padhee, S.; Nayak, N.; Panda, S.K.; Dhal, P.R. \& Mahapatra, S.S. (2012). Multiobjective parametric optimization of powder mixedelectro-discharge machining using response surfacemethodology and non-dominated sorting genetic algorithm.Indian Academy of Sciences, 37(2), 223-240.

Pecas, P. \& Henriques, E. (2003). Influence of silicon powder-mixed dielectric on conventional electrical discharge machining. International Journal of Machine Tools \& Manufacture, 43, 1465-1471.

Pecas, P. \& Henriques, E. (2008). Electrical discharge machining using simple and powder-mixed dielectric: the effect of the electrode area in the surface roughness and topography.Journal of Materials Processing Technology, 200, 250-258.

Prabu, M.; Ramadoss, G.; Senthilkumar, C.; Boopathi, R. \& Magibalan, S. (2015). Experimental Investigation on effect of graphite powder suspended dielectric in electric discharge machining of Al-TiB2 composites. Journal of Chemical and Pharmaceutical Sciences, pp. 52-54. 
Rajendra, M. \& Rao, G.K.M. (2014). Experimental evaluation of performance of electrical discharge machining of D3 die steel with Al2O3 abrasive mixed dielectric material by using design of experiments. International Journal of Research in Engineering and Technology, 3(1), 599-606.

Ramesh, S. \& Jenarthanan, M.P. (2018). Investigating the performance of powder mixed electric discharge machining of Nimonic 75 by using different tool materials. World Journal of Engineering, 15(2), 205-215.

Razak, M.A.; Abdul-Rani, A.M. \& Nanimina, A.M. (2015). Improving EDM efficiency with silicon carbide powder-mixed dielectric fluid. International Journal of Materials, Mechanics and Manufacturing 3(1), 40-43.

Rouniyar, A.K. \& Shandilya, P. (2018). Multi-Objective Optimization using Taguchi and Grey Relational Analysis on Machining of Ti-6Al-4V Alloy by Powder Mixed EDM Process. Materials Today: Proceedings, 5, 23779-23788.

Rouniyar, A. \& Shandilya, P. (2019,a). Fabrication and experimental investigation of magnetic field assisted powder mixed EDM on machining of aluminum 6061 alloy. Proceedings of the Institution of Mechanical Engineers, Part B: Journal of Engineering Manufacture, 233(12), 2283-2291.

Rouniyar, A. \& Shandilya, P. (2019,b). Experimental study on material removal rate of Al6061 machined with magnetic field assisted powder mixed electrical discharge machining. Journal of Physics Conference Series, 1240(1), 012018.

Rouniyar, A. \& Shandilya, P. $(2019, \mathrm{c})$. Analysis and optimization of tool wear rate in magnetic field-assisted powder-mixed electrical discharge machining of Al6061 alloy using TLBO. Advances in Computational Methods in Manufacturing, Chapter 42, Springer. (In Press)

Rouniyar, A. \& Shandilya, P. (2019,d). Improvement in machined surface with the use of powder and magnetic field assisted on machining aluminium 6061 alloy with EDM. IOP Conference Series: Materials Science and Engineering. (Accepeted for Publication).

Roy, C.; Syed, K.H. \& Kuppan, P. (2016). Machinability of Al/10\%SiC/2.5\%TiB2 metal matrix composite with powder-mixed electrical discharge machining. Global Colloquium in Recent Advancement and Effectual Researches in Engineering, Science and Technology, Procedia Technology, 25, 1056-1063.

Shandilya, P.; Jain, P.K.\&Jain, N.K. (2016). Modelling and process optimisation for wire electric discharge machining of metal matrix composites. Int. J. Machining and Machinability of Materials, 18(4),377-391.

Sharma, S.; Kumar, A.; Beri, N. \& Kumar, D. (2010). Effect of aluminium powder addition in dielectric during electric discharge machining of Hastelloy on machining performance using reverse polarity. International Journal of Advanced Engineering Technology, 1(3), 13-24.

Sahu, D.R.; Kumar, A.; Roy, B. K. \& Mandal, A. (2019). Parametric investigation into alumina nanopowder mixed EDM of Inconel 825 alloy using RSM. Advances in Industrial and Production Engineering, 175-184. doi:10.1007/978-981-13-64129_16 
Sidhu, S.S.; Batish, A. \& Kumar, S. (2014). Study of surface properties in particulatereinforcedmetal matrix composites (MMCs) using powder-mixedelectrical discharge machining (EDM). Materials and Manufacturing Processes 29, 46-52.

Singh, A. \& Singh, R. (2015). Effect of powder mixed electric discharge machining (PMEDM) on various materials with different powders: A review. International Journal for Innovative Research in Science \& Technology 2(3), 164-169.

Singh, G.; Singh, P.; Tejpal, G. \& Singh, B. (2012). Effect of machining parameters on surface roughness of $\mathrm{H} 13$ steel in EDM process using powder mixed Fluid. International Journal of Advanced Engineering Research and Studies, 2(1), 148-150. Singh, P.; Kumar, A.; Beri, N. \& Kumar, V. (2010). Some experimental investigation on aluminum powder mixed EDM on machining performance of Hastelloy steel. International Journal of Advanced Engineering Technology, 1(2), 28-45.

Singh, S. \& Yeh, M.F. (2012). Optimization of abrasive powder mixed EDM of aluminum matrix composites with multiple responses using gray relational analysis. Journal of Materials Engineering and Performance, 21(4), 481-491.

Syed, K.H. \& Palaniyandi, K. (2012). Performance of electrical discharge machining using aluminium powder suspended distilled water. Turkish Journal of Engineering and Environmental Sciences, 36, 195-207.

Talla, G.; Sahoo, D.K.; Gangopadhyay, S. \& Biswas, C.K. (2015). Modeling and multi-objective optimization of powder mixed electric discharge machining process of aluminum/alumina metal matrix composite. Engineering Science and Technology, an International Journal, 18, 369-373.

Tripathy, S. \& Tripathy, D.K. (2016). Multi-attribute optimization of machining process parameters in powder mixed electro discharge machining using TOPSIS and grey relational analysis. An International Journal of Engineering Science and Technology, 19, 62-70.

Tzeng, Y.F. \& Lee, C.Y. (2001). Effects of powder characteristics on electro discharge machiningefficiency. International Journal of Advanced Manufacturing Technology, 17, 586-592.

Vhatkar, D.R. \& Jadhav, B.R. (2013). An experimental study on parametric optimization of high carbon steel (EN-31) by using silicon powder mixed dielectric EDM process. International Journal of Science and Research, 2(1), 431-436.

Vishwakarma, M., Parashar, V. \& Khare, V.K. (2012).Advancement in Electric Discharge Machining on metal matrix composite materials in recent: A Review. International Journal of Scientific and Research Publications, 2(3),1-8. 